\title{
MARTIN DAHL
}

SEU Georgian National University

ORCID: 0000-0003-1978-7045

augwaw@gmail.com

\section{The European Green Deal and the Social Market Economy}

\section{Europejski Zielony Ład a społeczna gospodarka rynkowa}

\section{Słowa kluczowe:}

Europejski Zielony Ład, ordoliberalizm, społeczna gospodarka rynkowa, integracja europejska
Keywords:

European Green Deal, Ordoliberalism, Social Market Economy, European Integration 


\section{The European Green Deal and the Social Market Economy}

The European Green Deal is an attempt to transform the European Union's economy in order to achieve climate neutrality by 2050 . This is to counteract undesirable climate change and environmental degradation. In this context, an interesting question is whether the implementation of the European Green Deal is in line with the European Union's model of the Social Market Economy. In order to be able to answer this research question, this study is divided into five parts. The first is an introduction to the analysed issues. The second part presents the basic assumptions of the European Green Deal. The third presents the most important assumptions of the Social Market Economy in the context of climate policy. The fourth part analyses the coherence of the European Green Deal with the model of the Social Market Economy. The study ends with a summary containing the conclusions of the conducted research.

\section{Europejski Zielony Ład a społeczna gospodarka rynkowa}

Europejski Zielony Ład to próba przekształcenia gospodarki Unii Europejskiej w celu osiągnięcia neutralności klimatycznej do 2050 roku. Ma to przeciwdziałać niepożądanym zmianom klimatycznym i degradacji środowiska. W tym kontekście interesujące jest pytanie, czy realizacja Europejskiego Zielonego Ładu jest zgodna z unijnym modelem społecznej gospodarki rynkowej? Aby móc odpowiedzieć na to pytanie badawcze, niniejsze opracowanie zostało podzielone na pięć części. Pierwsza to wprowadzenie do analizowanych zagadnień. W drugiej części przedstawiono podstawowe założenia Europejskiego Zielonego Ładu. Część trzecia przedstawia najważniejsze założenia społecznej gospodarki rynkowej w kontekście polityki klimatycznej. Część czwarta to analiza spójności Europejskiego Zielonego Ładu z modelem społecznej gospodarki rynkowej. Artykuł kończy podsumowanie zawierające wnioski z przeprowadzonych badań. 


\section{Introduction}

The first two decades of the 21st century are a period of numerous global crises and challenges. These are visible at almost every level - political, economic, social and, above all, environmental. Climate change is so serious, widespread and rapidly progressing that governments have recognised the need to regulate the environmental impact of activities carried out by states and enterprises. At the dawn of the third decade of the 21st century, the world is inhabited by nearly eight billion people, who together account for more than 130 trillion euros of global gross domestic product (GDP) measured in purchasing power parity. This translates into enormous economic, social and environmental problems, structural imbalances and numerous conflicts, both on the international stage and within the societies concerned. It is indisputable that we are living in times when a new reality is emerging, which must first be understood and explained in order to create the desired shape. ${ }^{1}$

At the moment, global climate change is one of the greatest challenges facing the European Union, because in the near future it will lead to a number of other problems, such as international population migrations, the loss of the planet's biodiversity, problems with access to drinking water, and so on. This in turn will have a significant impact on social and economic spheres. It can be assumed with a high degree of probability that this will intensify existing conflicts over access to limited resources and will also contribute to a deepening of existing economic and social disparities. It should be noted that most of the climate changes are not caused by human action alone. They are also significantly influenced by common business models, which often have a negative impact on the environment ${ }^{2}$, and by the capitalist economic model prevailing in most countries, in which dominant market forces do not face sufficient counterbalance, fuelling numerous instabilities that are increasingly difficult to prevent and resolve. An example of such an undesirable tendency is the emergence of economic organisations that are more powerful

1 G. W. Kołodko, Ekonomia nowego pragmatyzmu: tożsamość, cele, metoda, „Biuletyn PTE" 2019, no. 4, p. 31.

2 P.Sałagan, M. Pietrzczyk, Europejski Zielony Ład - szansa czy zagrożenie?, EY [online], 5 X 2020 [access: 5 VI 2021]: <https://www.ey.com/pl_pl/business-5-o/ europejski-zielony-lad-szansa-czy-zagrozenie $>$. 
than many countries in terms of capital ${ }^{3}$ which, through their activities, often contribute to the degradation of the natural environment or exacerbate existing social problems. The European Green Deal is the European Union's response to the challenges posed not only by climate change but also by social and environmental problems.

Looking back to the origins of the Social Market Economy, one should go back to the 1920 s - the beginnings of the ordoliberal school in the social sciences. Its practical implementation was initiated in West Germany after the end of World War II. This model was also developed to a considerable extent in Scandinavian countries. ${ }^{4}$ It became one of the reference points for political and socio-economic reforms in numerous countries undergoing systemic transformation - especially in Central and Eastern Europe. The key step in the practical implementation of ordoliberal principles in the West Germany's socio-economic policy was the economic and currency reform initiated by Ludwig Erhard, the then Minister of Economic Affairs, on 20 June 1948. It consisted of a break with the centrally controlled economy and the introduction of a market economy. ${ }^{5}$ Historically, the model of so-called German capitalism based on a Social Market Economy seemed to be particularly attractive as it was based on the experience of shifting from a centrally controlled economy to a market economy. Nowadays more and more attention is being paid to the element of the state shaping the systemic framework necessary for the proper functioning of the economy, the social sphere or increasingly important environmental issues. The everyday practice has revealed the weaknesses of the neoliberal doctrine popular at the end of the 2oth century. Its effectiveness in solving problems - especially social problems - proved to be insufficient. This applies

3 J. Hausner, Ekonomia i społeczne imaginarium, „Biuletyn PTE” 2019, no. 4, p. 27.

4 E. Mączyńska, Ordoliberalizm i społeczna gospodarka rynkowa jako podstawa inkluzywnego systemu społeczno-gospodarczego, [in:] Społeczna Gospodarka Rynkowa: Polska i integracja europejska, eds E. Mączyńska, P. Pysz, PTE, Warsaw 2018, p. 172.

5 H.Schmieding, Deutschlands Weg zur Marktwirtschaft: Die westdeutsche Währungsreform von 1948 und die gesamtdeutsche Währungssunion von 1990 im Verg̈leich, „ORDO. Jahrbuch für die Ordnung von Wirtschaft und Gesellschaft“ 1991, vol. 42, pp. 189-211; F. A. Lutz, The German currency reform and the revival of the German economy, "Economica" 1949, vol. 16, no. 62, pp. 122-142; Social Market Economy principles and implementation-economy policy from A to Z, eds R. H. Hasse, H. Schneider, K. Weigelt, Konrad-Adenauer-Stiftung, Singapore 2008. 
equally to climate issues. This naturally implies the need to seek new solutions, also at the level of systemic doctrines. It is also reasonable to refer to existing concepts, such as the Social Market Economy, which involves an active role of the state in shaping both the socio-economic order and, in light of new challenges, the environmental order.

For decades, the member states of the European Union have been trying, with various success, to implement measures to protect the climate and the natural environment. Implementation of the increasingly popular concept of sustainable development leaves much to be desired, and global agreements to combat climate change have proved insufficient to halt it. We are still witnessing a growing level of global consumption, exploitation of natural resources and excessive focus exclusively on the material aspects of economic development, with simultaneous marginalisation of elements affecting the quality of human life. This task is not being fulfilled either by the formation of a new multipolar international order, which intensifies the rivalry between world powers in the economic or military sphere. ${ }^{6}$ Paradoxically, this state of affairs could be an opportunity for the European Union, which is less and less able to compete in economic or military terms with great powers such as the USA and China. Setting global standards in the field of environmental protection, the development of modern technologies in this area and the popularisation of ecological values may be an opportunity to strengthen the global position of the European Union and become a point of reference for other countries, for which issues relating to environmental protection will become increasingly important. In addition, promoting a system based on a market economy, in which the state's economic policy must be consistent with social and environmental policy, could become a significant incentive for the economic and social development of European Union member states. Therefore, an interesting research question is to what extent is the European Green Deal consistent with the model of the Social Market Economy in the European Union, which member states are obliged to implement. Referring to the ordoliberal theory and analysing selected documents and publications, this paper will attempt to answer the question of consistency and complementarity of the assumptions of the European Green Deal with the model of the Social Market Economy.

6 J.M. Fiszer, System euroatlantycki $i$ bezpieczeństwo międzynarodowe $w$ multipolarnym świecie, „Myśl Ekonomiczna i Polityczna” 2013, no. 2, p. 130. 


\section{Basic principles of the European Green Deal}

In December 2019, the new President of the European Commission, Ursula von der Leyen, presented a new strategy for the development of Europe called the European Green Deal. It is a political initiative to achieve climate neutrality by the European economy by 2050 . This means that in 2050 , $\mathrm{CO}_{2}$ emissions in Europe cannot be higher than the amount of $\mathrm{CO}_{2}$ that will be absorbed, for example by forests or captured and stored underground.? At the same time, an increase in the already ambitious targets to reduce greenhouse gas emissions in the atmosphere by $60 \%$ by 2030 is being considered. The Green Deal also aims to increase resource efficiency, reduce pollution levels and protect biodiversity on the continent while ensuring social justice. Unlike other EU development strategies, or energy strategies, or even the earlier climate targets, the European Green Deal is characterised by a comprehensive and holistic approach. ${ }^{8}$ According to the accompanying roadmap for the European Green Deal, the new legal framework and guidelines necessary for its implementation are to be implemented following a review and adjustment of European legislation.

Implementing the European Green Deal in practice will mean that almost all sectors will have to be decarbonised by 2050 . All scenarios leading to climate neutrality assume a complete phase-out of coal. The share of renewable energy sources will have to increase significantly. The roles of natural gas as a transition fuel between coal and zero-carbon energy sources, and nuclear energy in achieving the targets, are controversial. Climate neutrality will require large sums of money to be invested in renewable energy sources or in technologies that will allow $\mathrm{CO}_{2}$ to be taken out of the atmosphere. Far-reaching changes will also be needed in all sectors of the EU economy and in the lifestyle of Europeans. Undoubtedly, people in regions with high-emission industries or coal mining will be most affected by the changes. ${ }^{9}$

7 K. Bolesta, M. Korolec, Polityka klimatyczna jako niezależny element polityki zagranicznej Unii Europejskiej - wnioski dla Polski, "Sprawy Międzynarodowe" 2020, vol. 73, no. 1, p. 53, DOI: 10.35757/SM.2020.73.1.08.

8 Z. Nowak, Europejski Zielony Ład - na drodze do neutralności klimatycznej UE, „Biuletyn PISM” 2021, no. 66.

9 P. Wiejski, Zielony Ład dla Europy. Uwarunkowania, narzędzia, perspektywy, Instytut Spraw Publicznych, Warszawa 2019:〈https://www.isp.org.pl/pl/publikacje/zielonylad-dla-europy-uwarunkowania-narzedzia-perspektywy $>$ [access: 6 VI 2021]. 
For these groups of people, active social policy measures will be necessary to adapt to the new reality.

According to the assumptions adopted by the European Commission, implementation of the European Green Deal will require rethinking of policies for clean energy supply throughout the economy, in industry, production and consumption, large-scale infrastructure, transport, food and agriculture, construction, taxation and social benefits. The areas requiring the most change will be the protection and restoration of natural ecosystems, the sustainable use of resources and the protection of human health. It is in these areas that transformation can bring the greatest benefits to the EU's economy, society and environment. ${ }^{10}$ The necessary digital transformation is also an important part of implementing the European Green Deal.

Climate neutrality will apply to the entire European economy. The European Green Deal is also a blueprint for the transition to a clean, closed-loop economy that will reduce pollution and maintain biodiversity. Social issues are an important aspect of this - a just transition and a commitment not to leave anyone behind. The European Green Deal goes well beyond economics, demonstrating a new, socially and environmentally sustainable vision for the development of the EU Member States. ${ }^{11}$

\section{Basic assumptions of the ordoliberal Social Market Economy model in the context of environmental policy}

Social issues are a very important element of the Social Market Economy model. Social policy for ordoliberals is in fact a counterbalance to unrestrained economic processes, which create inequalities and destructive consequences for society if left to their own devices. Correction in the form of social policy is necessary for the market to function more efficiently. An analogous regularity applies to environmental issues. Within this conceptualisation of the economy, social or environmental policy has

10 Communication from the Commission. The European Green Deal, Brussels, EUR-lex, 11 XII 2019: <https://eur-lex.europa.eu/legal-content/EN/TXT/?qid=1576150542719\&ur $\mathrm{i}=\mathrm{COM} \% 3 \mathrm{~A} 2019 \% 3 \mathrm{~A} 640 \% 3 \mathrm{AFIN}>$ [access: 06 VI 2021].

11 A. Gawlikowska-Fyk, Polska w Zielonym Ładzie - korzyści, możliwości i ocena SWOT, Kancelaria Senatu, Warszawa 2020, p. 4 (Opinie i ekspertyzy OE-307). 
a corrective function for the imperfections caused by the functioning of the free market, which allows the individual to participate fully in economic life. Importantly, all of this is to be achieved through the rule of law, strengthening the economic constitution binding the state, and enabling and compelling the state to act as guarantor of these principles. ${ }^{12}$

Ordoliberalism challenges the views of classical liberals about the invisible hand of the market', that is the self-regulation of the market mechanism. ${ }^{13}$ In the light of this theory, in order to be able to preserve the natural order, it is necessary to consciously influence it by creating an appropriate institutional and legal framework within which spontaneous market forces can be formed and developed. The solution to the problem of directing the economic process in the ordoliberal perspective means a situation in which, within the framework of the productive potential of the economy at its disposal, the state does everything to satisfy the material needs of society. Ludwig Erhard stressed this particularly strongly, being convinced that the task of a market economy is first and foremost to satisfy the needs of consumers, and through this to raise the standard of living of the widest possible strata of society. ${ }^{14}$

The implementation of the Social Market Economy in the European Union is mainly the result of its primary law. In the context of economic policy, the EU's legal system is based on the assumption that it must be consistent with the assumptions of the Social Market Economy model, which is the result of the treaties signed by the Member States and the consequence of respect for fundamental legal values, which can be found in the European Charter of Fundamental Rights. ${ }^{15}$ If the individual with freedom of will and freedom of contract is at the heart of the legal system of the EU states, then the economic policies of the EU states - including

J. Mulder, (Re) Conceptualising a Social Market Economy for the EU internal market, "Utrecht Law Review" 2019, vol. 15, issue 2, pp.21-23.

13 H. Lampert, A. Bossert, Sozialstaat Deutschland, Verlag Vahlen, München 1992, p. 22.

14 A. Peacock, H. Willgerodt, Germany's social market economy. Origins and evolutions, Macmillan, London 1989.

15 U. Di Fabio, Green Recovery: Rechtsmaßstäbe für den ökologischen Umbau der Wirtschaft, [in:] Chancen und Risiken in der Politik des Green Deal, Jahresheft des Wissenschaftlichen Beirats der Stiftung Familienunternehmen, Stiftung Familienunternehmen, München 2021, p. 13. 
ambitious policies for ecological transformation and effective climate protection - must be subject to the systemic framework defined by the Social Market Economy model. The framework must be respected; it must not be overstepped.

The Social Market Economy is based primarily on a competition-neutral regulatory policy. State regulation of markets is seen as consistent with the state economic system only where oligopolies or monopolies exist that distort the functioning of the market mechanism, thereby limiting or preventing potential state control and intervention. For market participants, stability and predictability of operation are of fundamental importance, thanks to which planning security is ensured. Regulatory stability always benefits investments with medium and long-term effects and is therefore essential to protect acquired property and future freedom of action under the rule of law. Certain control instruments, such as carbon certificates, for example, can be a regulatory element, and their trade does not conflict with the market economy. Going one step further, it could even be argued that in the Social Market Economy model, they are a regulatory element which, in the case of specific threats (and excessive $\mathrm{CO}_{2}$ emissions can certainly be regarded as such a threat), makes it possible to assess the risk or possible infringement of competition.

The concept of the Social Market Economy has had a major impact on many European countries. With the entry into force of the Maastricht Treaty in 1993, it can be considered the dominant model of socio-economic governance in the European Union. ${ }^{16}$ This is clearly stated in Article 3(3) of the Treaty on European Union, which states that 'The Union shall establish an internal market. It shall work for the sustainable development of Europe based on balanced economic growth and price stability, a highly competitive Social Market Economy, aiming at full employment and social progress, and a high level of protection and improvement of the quality of the environment'. ${ }^{17}$ In particular, improving the quality of the environment requires stopping the negative trends in its degradation. Crucial in this respect, in addition to political will and technological

16 K. Kamińska, Społeczna gospodarka rynkowa jako model ładu gospodarczego Unii Europejskiej, „Ekonomia” 2013, no. 4(25), p. 229.

17 Wersje skonsolidowane Traktatu o Unii Europejskiej i Traktatu o funkcjonowaniu Unii Europejskiej, Dziennik Urzędowy Unii Europejskiej 2012/C 326/01. 
progress, is greater ecological awareness, which will allow a different view of the relationship between the human species and nature. ${ }^{18}$ This requires a change in the approach to the management process itself and the inclusion in the economic indicators of criteria such as the quality of health care, the natural, political and cultural environment. ${ }^{19} \mathrm{~A}$ change in environmental awareness must entail a change in lifestyle, although this is an uncomfortable prospect for those profiting from the economic system as it stands. ${ }^{20}$

The member states of the European Union have been striving for decades to shape the type of economic and social system which, on the one hand, would be characterised by high economic efficiency and, on the other hand, would ensure protection against social exclusion and poverty and guarantee environmental protection. It is usually impossible to fulfil two important requirements at the same time: efficiency of the economic system and effective social and environmental policy. In the concept of a Social Market Economy, however, we are dealing with an attempt to achieve all these goals simultaneously by building the political and socio-economic system on the following three pillars:

1. Competitive order, which increases the efficiency of the economic process, especially in countries where the role of the state in economic life was excessive (e.g. post-communist countries).

2. Deconcentration order, the aim of which is to maintain a high level of employment (in the best case this would be full employment) and to spread an entrepreneurial culture.

3. Political democracy based on the principle of subsidiarity and decentralisation of power, which should be limited as civil society develops.

The Social Market Economy has determined the operating framework for the market economy in numerous European countries for decades. A sound economy demonstrates a capacity for long-term growth that sustains the right relationship between the present and the future. In practice, this means not only cost-effective production and fairness, but, as Grzegorz Kołodko aptly put it, also 'social cohesion and solidarity,

18 B. Baran, Współczesne wyzwania ekologiczne - w kierunku homo oecologicus?, „Optimum. Studia Ekonomiczne" 2017, no. 6, p. 7, DOI: 10.15290/ose.2017.06.90.01.

19 G. W. Kołodko, Ekonomia nowego ..., p. 35.

20 B. Baran, Współczesne wyzwania ..., p. 8. 
generational responsibility and environmental awareness. ${ }^{21}$ Environmental awareness is of particular importance at the present time. We are currently facing qualitatively different and complex environmental challenges. This new dimension of challenges is represented by climate change and species extinction. A common feature of today's environmental problems is that they are escalating very rapidly, while at the same time underestimating the rate, intensity and sustainability of climate change. The measures taken so far to protect the environment are no longer sufficient. Radical structural changes are now needed in technological, economic and systemic areas. This awareness is growing. Many people have realised that we cannot pass on the costs of our lifestyle and economy to future generations. ${ }^{22}$

\section{Elements of the Social Market Economy in the European Green Deal}

The Green Deal itself aims to transform the economies of the EU Member States with a view to achieving climate neutrality in 2050. For many industries, this means a range of measures related not only to the Green Deal, but also to the social changes that follow. These primarily concern legal regulations, but also focus on issues of environmental and social responsibility of the state, entrepreneurs and citizens. The European Green Deal also refers to the concept of sustainable development, outlining the actions and goals the EU will focus on in the coming years. An important element of these are the social issues which are central to the Social Market Economy model.

The European Green Deal also refers to the concept of the Circular Economy. It refers to production and consumption in which the usage of raw materials is reduced as much as possible, the life cycle of a product is extended and, consequently, the amount of waste generated, as well as emissions and energy losses, are reduced by creating a closed cycle in which waste from one process is used as raw materials in others. This allows

21 G. W. Kołodko, Ekonomia nowego ..., pp. 32-33.

22 U. Heinen-Esser, Möglichkeiten auf Landesebene: Umweltpolitik in der Sozialen Marktwirtschaft, in: Wohlstand für Alle - Klimaschutz und Marktwirtschaft, LudwigErhard-Stiftung, Bonn 2020: 〈https://www.ludwig-erhard.de/wp-content/uploads/ Ludwig-Erhard-Stiftung-2020_Wohlstand-f\%C3\%BCr-Alle_Klimaschutz-undMarktwirtschaft.pdf> [access: 5 VI 2021]. 
production and consumption waste to be minimised. ${ }^{23} \mathrm{~A}$ very important aspect of the Green Deal is the legislation that will gradually be implemented both at European and national level. Regulations aimed at achieving climate neutrality or applying the principles of the Circular Economy will force changes in companies and are expected to lead to changes in the structure of consumption. From the point of view of the Social Market Economy model, it is important that the European Commission assumes the implementation of relevant regulations on the basis of the principle of subsidiarity and in a spirit of solidarity with other countries. An expression of this approach may be the will to allocate additional funds for energy transformation to those regions in the European Union whose energy consumption is based mainly on fossil fuels, and in particular hard coal.

The European Green Deal is to be achieved through three instruments: (1) the Climate Law Regulation, (2) an industrial policy geared towards environmental change, and (3) an action plan to strengthen the Circular Economy. ${ }^{24}$ All of these instruments can have a significant impact on the labour market, lead to the creation of new jobs and thus contribute to strengthening one of the fundamental principles of the Social Market Economy - the pursuit of full employment. It should be borne in mind, however, that investment in climate policy to improve the climate balance may initially lead to an increase in production costs, whether through a $\mathrm{CO}_{2}$ tax or a ban on using certain materials. From a macroeconomic perspective, this is a factor that weakens competitiveness and may lead to a reduction in demand, but it is in line with Walter Eucken's principle of the responsibility of economic actors for the external effects of their activities. ${ }^{25}$

When implementing the principles of the European Green Deal, particular attention should be paid to the associated risk of reducing the competitiveness of member states' economies. It is important that interventions as part of climate policy create a technological impulse which would

23 P. Sałagan, M. Pietrzczyk, Europejski Zielony Ład...

24 H. Schneider, Wie der "Green Deal“ der EU auf den Arbeitsmarkt einwirkt, LudwigErhard-Stiftung [online], 22 IX 2020 [access: 6 VI 2021]: <https://www.ludwig-erhard. de/erhard-aktuell/standpunkt/wie-der-green-deal-der-eu-auf-den-arbeitsmarkteinwirkt/>.

25 W. Eucken, Grundsätze der Wirtschaftspolitik, 7th edition, UTB, Tübingen 2004. 
enable more efficient production and thus allow a high level of competitiveness to be maintained. Technical innovations are a source of ever-increasing prosperity. These arise primarily where financial profitability is high. Research into efficient and environmentally friendly energy production and more effective energy consumption is crucial in this respect. In this context, it is also justified to strive to strengthen the Circular Economy ${ }^{26}$. The European Union should use the green transition of the economy to expand the use of renewable energies, reduce fossil fuel imports and set global standards for climate protection ${ }^{27}$. The European Union's implementation of ambitious climate targets is an opportunity to strengthen the competitiveness of member states by promoting European technologies and companies that could become global leaders.

\section{Summary}

These days one can observe growing criticism of capitalism, and calls for radical interventions in production and consumption are becoming more frequent, but are they legitimate and right? It is highly questionable whether the introduction of an ecological crisis regime based on central planning is the path that will help to halt negative climate change. For the preservation of the market mechanism as the primary factor in the allocation and distribution of wealth and scarce resources, there is hardly any alternative at present. So what could lead to greater social cohesion and justice, respect for the environment and the prospect of sustainable development in the future? It seems that an alternative to the current model of capitalist economy based on neo-liberalism may be a return to the original principles of the Social Market Economy and the inclusion of environmental issues. A threefold transformation of industrial society should be pursued: firstly, a shift from fossil fuels to renewable energy sources; secondly, a steady increase in resource efficiency, and thirdly, a shift to a Circular Economy in which all residues are returned to biological or industrial sources. Growth in itself is not harmful to the environment. It is not GDP that determines the environmental balance of an economy, but the issue of environmentally

26 H. Schneider, Wie der "Green Deal"..

27 K. Bolesta, M. Korolec, Polityka klimatyczna..., p. 54. 
friendly production of energy, industrial processes, agriculture and transport. In a shrinking economy, investment and the rate of innovation also fall. Precisely because time is of the essence in the context of climate change, we need faster ecological structural change ${ }^{28}$. The basis for a sustainable, green and Social Market Economy is the inclusion of environmental costs in setting prices. This can be achieved by a tax reform that gradually raises the price of greenhouse gas emissions and consumption of scarce natural resources. The additional burden caused by environmental taxes can be returned to all citizens in the form of a lump-sum environmental premium. In line with the tax policy defined in the Social Market Economy model, this step would have a positive redistributive effect, as people with low earnings tend to have a smaller carbon footprint than wealthy people. The stimulus packages and investment programmes to boost economic growth after the COVID-19 pandemic that are currently being developed by individual member states and the European Union should combine two objectives: to accelerate the digitalisation of the $\mathrm{EU}$ and at the same time, accelerate green structural change. The growing public debt should also not be forgotten. There will be no second chance for a large-scale green investment programme in the near future. Therefore, close coordination between national and EU-funded programmes is necessary in order to achieve optimal synergies. Public support for the implementation of climate policy is also important. This will only be possible if economic and social issues are properly addressed. It was proper attention to economic and social issues that became the source of the success of the implementation of the Social Market Economy in Germany after World War II.

In spite of numerous difficulties, the European Commission has managed to create the conceptual and financial framework for systemic changes to the European Green Deal in 2020. The allocation of unprecedented financial resources for climate protection heralds a more ambitious approach by the European Commission to the implementation of the European Green Deal than has been the case to date. This is supported by the attitude of EU citizens, $93 \%$ of whom see climate change as a serious problem (according to a Eurobarometer survey) and a similar majority who believe

28 R. Fücks, Eine ökologisch-soziale Marktwirtschaft, Ludwig-Erhard-Stiftung [online], 3 VIII 2020 [access: 7 VI 2021]: <https://www.ludwig-erhard.de/erhard-aktuell/ standpunkt/eine-oekologisch-soziale-marktwirtschaft/>. 
that member state governments should step up climate action. The EU's idea of leadership by example obliges the European Commission to continuously increase its ambitions on climate protection, especially in the context of announcements by China, Japan, South Korea and the United States of plans to achieve climate neutrality, as well as competing to be a global leader in climate transformation ${ }^{29}$.

The European Green Deal is conceived as a strategy for economic modernisation and growth. It also represents a unique opportunity to initiate and accelerate the energy transition. It can bring about lasting change for both people and the environment. The fight against climate change is a global undertaking requiring the cooperation of all of us. However, it must go hand in hand with economic development and social progress. The EU's far-reaching climate protection targets are a necessary and laudable step and, most importantly, fit in with the European Union's Social Market Economy model.

\section{Bibliography}

Baran B., Współczesne wyzwania ekologiczne - w kierunku homo oecologicus?, „Optimum. Studia Ekonomiczne" 2017, no. 6, pp. 3-11, DOI: 10.15290/ose.2017.06.90.01.

Bolesta K., Korolec M., Polityka klimatyczna jako niezależny element polityki zagranicznej Unii Europejskiej - wnioski dla Polski, "Sprawy Międzynarodowe" 2020, vol. 73, no. 1, pp. 43-62, DoI: 10.35757/sM.2020.73.1.08.

Communication from the Commission. The European Green Deal, Brussels, EUR-lex, 11 XII 2019: <https://eur-lex.europa.eu/legal-content/EN/TXT/?qid=157615054271 9\&uri $=$ сом $\% 3$ A2019\%3A640\%3AFIN > [access: 06.06.2021].

Di Fabio U., Green Recovery: Rechtsmaßstäbe für den ökologischen Umbau der Wirtschaft, [in:] Chancen und Risiken in der Politik des Green Deal, Jahresheft des Wissenschaftlichen Beirats der Stiftung Familienunternehmen, Stiftung Familienunternehmen, München 2021.

Eucken W., Grundsätze der Wirtschaftspolitik, 7th edition, UTB, Tübingen 2004.

Fiszer J.M., System euroatlantycki i bezpieczeństwo międzynarodowe $w$ multipolarnym świecie, „Myśl Ekonomiczna i Polityczna” 2013, no. 2.

Fücks R., Eine ökologisch-soziale Marktwirtschaft, Ludwig-Erhard-Stiftung [online], 3 VIII 2020 [access: 7 VI 2021]: <https://www.ludwig-erhard.de/erhard-aktuell/ standpunkt/eine-oekologisch-soziale-marktwirtschaft/>. 
Gawlikowska-Fyk A., Polska w Zielonym Ładzie - korzyści, możliwości i ocena SWOT, Kancelaria Senatu, Warszawa 2020, p. 4 (Opinie i ekspertyzy OE-307).

Hausner J., Ekonomia i społeczne imaginarium, „Biuletyn PTE” 2019, no. 4.

Heinen-Esser U., Möglichkeiten auf Landesebene: Umweltpolitik in der Sozialen Marktwirtschaft, in: Wohlstand für Alle - Klimaschutz und Marktwirtschaft, Ludwig-Erhard-Stiftung, Bonn 2020: 〈https://www.ludwig-erhard.de/wpcontent/uploads/Ludwig-Erhard-Stiftung-2020_Wohlstand-f\%C3\%BCr-Alle_ Klimaschutz-und-Marktwirtschaft.pdf> [access: 5 VI 2021].

Kamińska K., Społeczna gospodarka rynkowa jako model ładu gospodarczego Unii Europejskiej, „Ekonomia” 2013, no. 4(25).

Kołodko G. W., Ekonomia nowego pragmatyzmu: tożsamość, cele, metoda, „Biuletyn PTE" 2019, no. 4.

Lampert H., Bossert A., Sozialstaat Deutschland, Verlag Vahlen, München 1992.

Lutz F. A., The German Currency Reform and the Revival of the German Economy, "Economica" 1949, vol. 16, no. 62, pp. 122-142.

Mączyńska E., Ordoliberalizm i społeczna gospodarka rynkowa jako podstawa inkluzywnego systemu społeczno-gospodarczego, [in:] Społeczna Gospodarka Rynkowa: Polska i integracja europejska, red. E. Mączyńska, P. Pysz, PTE, Warszawa 2018.

Mulder J., (Re) Conceptualising a Social Market Economy for the EU Internal Market, "Utrecht Law Review" 2019, vol. 15, issue 2.

Nowak Z., Europejski Zielony Ład - na drodze do neutralności klimatycznej UE, „Biuletyn PISM" 2021, no. 66.

Peacock A., Willgerodt H., Germany's social market economy. Origins and evolutions, Macmillan, London 1989.

Sałagan P., Pietrzczyk M., Europejski Zielony Ład - szansa czy zagrożenie?, EY [online], 5 X 2020 [access: 5 VI 2021]: 〈https://www.ey.com/pl_pl/business-5-o/ europejski-zielony-lad-szansa-czy-zagrozenie $\rangle$.

Schmieding H., Deutschlands Weg zur Marktwirtschaft: Die westdeutsche Währungsreform von 1948 und die gesamtdeutsche Währungsunion von 1990 im Vergleich, „ORDO. Jahrbuch für die Ordnung von Wirtschaft und Gesellschaft“ 1991, vol. 42, pp. 189-211.

Schneider H., Wie der "Green Deal“ der EU auf den Arbeitsmarkt einwirkt, LudwigErhard-Stiftung [online], 22 IX 2020 [access: 6 VI 2021]: <https://www.ludwig-erhard.de/erhard-aktuell/standpunkt/wie-der-green-deal-der-eu-auf-denarbeitsmarkt-einwirkt/>.

Social Market Economy Principles and Implementation-Economy Policy from A to Z, eds R. H. Hasse, H. Schneider, K. Weigelt, Konrad-Adenauer-Stiftung, Singapore 2008.

Wersje skonsolidowane Traktatu o Unii Europejskiej i Traktatu o funkcjonowaniu Unii Europejskiej, Dziennik Urzędowy Unii Europejskiej 2012/C 326/o1.

Wiejski P., Zielony Ład dla Europy. Uwarunkowania, narzędzia, perspektywy, Instytut Spraw Publicznych, Warszawa 2019:〈https://www.isp.org.pl/pl/publikacje/zielony-lad-dla-europy-uwarunkowania-narzedzia-perspektywy $>$ [access: 6 VI 2021]. 